\title{
Arquivos de Zoologia
}

Museu de Zoologia da Universidade de Sáo Paulo

Volume 45(esp.) :63-72, 2014

www.mz.usp.br/publicacoes

ISSN impresso: 0066-7870

www.revistas.usp.br/azmz

ISSN on-line: $2176-7793$

\section{MORPHOMETRY AND RELATIVE GROWTH OF THE BRAZILIAN \\ SARDINE, SARDINELLA BRASILIENSIS (STEINDACHNER, 1879) \\ IN THE SOUTHEASTERN BRAZILIAN BIGHT}

\author{
Simone Perin ${ }^{1}$ \\ André Martins VaZ-Dos-Santos ${ }^{2}$
}

\begin{abstract}
The Brazilian sardine, Sardinella brasiliensis, is a small pelagic clupeid fish distributed primarily between $22^{\circ} \mathrm{S}$ and $29^{\circ} \mathrm{S}$, where it forms large schools. The species is an important fishery resource and is targeted by purse seine vessels operating in the area. Although an extensive literature addresses various characteristics of the species, studies of its morphometry and relative growth are scarce. The aim of the present study was to analyze the relative growth based on body and otolith morphometry to identify the patterns characterizing the population. Monthly samples were obtained during 1985 and 1987, and data on total length, total weight and otolith length, height and weight were analyzed. The allometric model of Huxley $\left(y=a x^{b}\right)$ was fitted seasonally and by year, and regressions were compared among seasons and between years. The regression coefficient " $b$ " was tested (t-test) to identify isometry and allometry. A total of 603 sardines, with total lengths ranging from $120 \mathrm{~mm}$ to $229 \mathrm{~mm}$, were analyzed. The length-weight relationships tended to show positive allometry, whereas the total length-otolith measurement relationships tended to show negative allometry. The relative growth rates decreased during the year and showed the lowest values during spring in association with the peak of the spawning period. In contrast, the condition factor (coefficient " $a$ " of the allometric regression) increased gradually during the year until spring as a consequence of the increasing weight of the fish due to gonad maturation. Comparisons between the years analyzed also show that the fish grew faster during the collapse of the stock, in 1987. The methodology used in this study allowed the detection of this effect. This study established the historical pattern of relative growth and showed that morphometry and relative growth offer efficient tools for monitoring the sardine in the study area.
\end{abstract}

KeY-Words: Otolith; Sagitta; Allometric model; Population condition.

\section{INTRODUCTION}

The Brazilian sardine, Sardinella brasiliensis (Steindachner, 1879) (Teleostei: Clupeidae), is a species endemic to the Southeastern Brazilian Bight (SEBB), the region between the Cape of São Tomé, Rio de Janeiro, and the Cape of Santa Marta Grande, in Santa Catarina, although sporadic occurrences are

1. Instituto de Pesca. Programa de Pós-Graduação. E-mail: perinsi.bio@gmail.com

2. Universidade Federal do Paraná. Laboratório de Esclerocronologia. Rua Pioneiro, 2.153, Jardim Dallas, CEP 85950-000, Palotina, PR, Brasil. E-mail: andrevaz@ufpr.br

http://dx.doi.org/10.11606/issn.2176-7793.v45iespp63-72 
also known from Argentinian waters (Figueiredo \& Menezes, 1978; Rossi-Wongtschowski et al., 2009). This small pelagic fish forms schools in the neritic region to a depth of $100 \mathrm{~m}$ (Cergole \& Dias Neto, 2011). It presents a short life cycle, high rates of growth and high fecundity. Its life cycle is also influenced by environmental conditions (oceanographic and meteorology), food availability and fisheries (Saccardo \& Isaac-Nahum, 1985; Isaac-Nahum et al., 1988; Rossi-Wongtschowski et al., 1991; Checkley Jr. et al., 2009; Dallagnolo et al., 2010).

Sardinella brasiliensis is Brazil's most important fisheries resource. Since the 1970's catches have presented strong variations (Cergole \& Dias Neto, 2011; Instituto de Pesca, 2013; GEP/UNIVALI, 2013). Available biomass estimates (Rossi-Wongtschowski et al., 1991; FURG, 2010; Cergole \& Dias Neto, 2011) also reveal substantial fluctuation in its abundance. In order to monitor the sardine stock, special governmental programs were developed, such as PIEBS in the 1980's (Integrated Biological Studies of Sardine) and after ECOSAR (Prospection and assessment of the biomass of the sardine Sardinella brasiliensis on the Southeastern coast by hydroacoustic methods) (Cergole \& Dias Neto, 2011).

Due to its economic importance, the sardine has been subject of many studies including those investigating growth (Braga, 1982; 1987; RossiWongtschowski et al., 1982; Vazzoler et al., 1982; 1987; Saccardo et al., 1988; Cergole \& Valentini, 1994; Cergole \& Rossi-Wongtschowski, 2005; Fonteles-Filho et al., 2005; Vaz-dos-Santos et al., 2010; Cergole \& Dias Neto, 2011).

Huxley (1993)'s classic treatment of the theme of relative growth established a conceptual framework for the use of size relationships in morphometric studies. Morphometric relationships are useful for identifying species, in population studies, for quantifying fish health and for identifying regional differences within species, and are a prerequisite for the study of growth and age (Wootton, 1998; Cadrin \& Friedland, 1999; Swain \& Foote, 1999; Lizama \& Takemoto, 2000; Wilson et al., 2009).

The application of morphometry and relative growth to otolith development yields a powerful and accurate tool by combining the advantages of the allometric model with the study of otoliths, structures that are formed during the early development of fish (Campana, 2001). Ricker (1975) proposed the application of relative growth, the condition factor and length-weight relationships to population dynamics and fisheries biology. Subsequently, several studies have used morphometry and relative growth to describe otoliths and fish development (Yamaguti, 1979; Casselman, 1990; Hunt, 1992; Lombarte \& Lleonart, 1993; Lidster et al., 1994; Kerstan, 2000; Volpedo \& Echeverría, 2001; Aguirre, 2003; Strelcheck et al., 2003; Tuset et al., 2003; Monteiro et al., 2005; Megalofonou, 2006; Gomiero \& Braga, 2007; Vaz-dos-Santos et al., 2007; Wilson et al., 2009; Lorenzo et al., 2011).

Bervian et al. (2006) proposed alternatives to Huxley's model for describing relative growth based on otoliths, showing the importance of this tool applied to fishes. Kristoffersen (2007) reviewed the theme and the growth-rate effect related to von Bertalanffy estimates, showing the importance of a well-studied otolith-fish measurements relationships. Up to the present, only Rossi-Wongtschowski et al. (1982) and Vaz-dos-Santos et al. (2010) used this methodology to evaluate changes in the growth pattern of Sardinella brasiliensis.

The aim of this study was to evaluate the relative growth of Sardinella brasiliensis in the 1980's through the use of body and otolith morphometry. This information may serve as a reference for future comparisons aimed to understand the effects and causes of the temporal variation in the stock of $S$. brasiliensis.

\section{MATERIAL AND METHODS}

\section{Sampling and Environmental features}

Specimens of $S$. brasiliensis were obtained from commercial landings in the purse seine fishery along the continental shelf of the SEBB. Information on fishing sites was obtained from logbooks (Fig. 1). Monthly samples were obtained from January to December, 1985, and from January to August, 1987. The total length (Lt, mm), total weight (Wt, g) and sagittal otoliths were obtained for each specimen. The data and materials are stored at the Ichthyological Collection of the Sclerochronology Laboratory at Universidade Federal do Paraná.

According to Matsuura (1986) and Castro et al. (2006), the Southeastern Brazilian Bight is characterized by the presence of the Coastal Water (CW), a mixture of continental and neritic waters with low salinities (<33.5S); the Tropical Water (TW, $>20^{\circ} \mathrm{C}$, $>36.4 \mathrm{~S}$ ) predominating in the neritic region; the Subtropical Shelf Water (SSW) which is a mixture of CW and TW; and the South Atlantic Central Water (SACW, $6^{\circ} \mathrm{C}<20^{\circ} \mathrm{C}, 34 \mathrm{~S}<36 \mathrm{~S}$ ) closely related to the continental slope. Upwellings also contribute to improve the biological productivity, primarily off Cabo Frio and at $23^{\circ} \mathrm{S}-25^{\circ} \mathrm{S}$ (Braga \& Niencheski, 2006). 
In order to assess the environmental conditions at the fishing sites, monthly map plots of sea temperature and salinity at depths ( 5 to $50 \mathrm{~m}$ ) were analyzed (CARTON-GIESE SODA, 2013). Although data of these variables are not available for the entire area in the period studied, the presence of the Subtropical Shelf Water and some intrusions of cold waters during spring and summer, mainly in areas of upwellings were identified.

\section{Data analysis}

The data were grouped and the analyses were conducted seasonally (Summer $=$ January through March; Autumn = April through June; Winter = July through September; Spring $=$ October through December). Statistical descriptions of the samples were done in terms of total length. A subsampling procedure was used for otolith analysis. In this procedure, eight otoliths were selected for each $10 \mathrm{~mm}$ length class in each season. Otolith length (Lo, $\mathrm{mm}$ ) and height (Ho, mm) (Fig. 2) were measured with an ocular micrometer coupled to an Olympus stereomicroscope (2.5x) (Rossi-Wongtschowski et al., 1982). Otolith weight (Wo, g) was measured with an analytical weighing scale. These data were also described in statistic terms.

Morphometric analyses were conducted by fitting the allometric model $\left(y=\mathrm{ax}^{\mathrm{b}}\right)$ to the measurements (Huxley, 1993). Fits were obtained for each season by the iterative least squares method. The agreement between the models and the data was verified with the coefficient of determination $\left(\mathrm{r}^{2}\right)$ and a

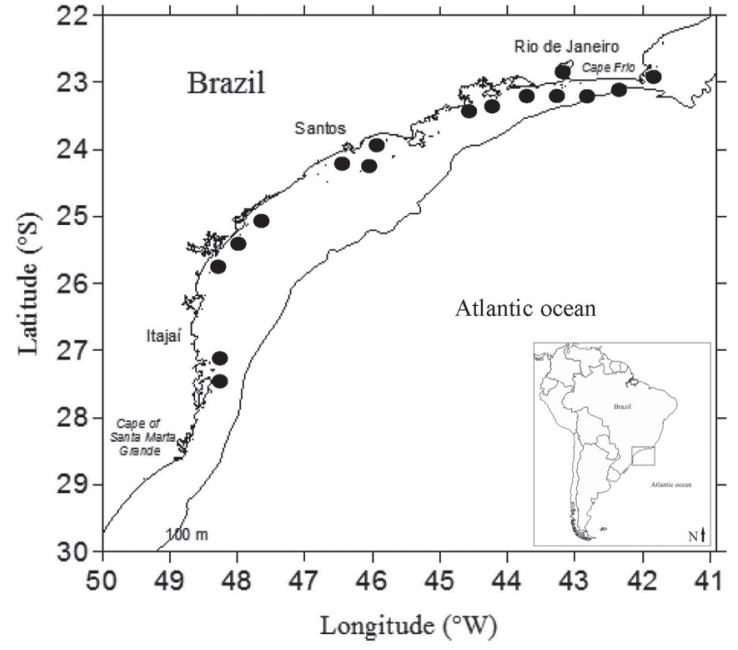

FIGURE 1: Fishing sites of purse seine fleet with catches and biological samples of Sardinella brasiliensis during 1985 and 1987 in the Southeastern Brazilian Bight.

standardized residual analysis (Vieira, 2006; Vaz-dosSantos \& Rossi-Wongtschowski, 2013). Morphometric relationships were fitted between $\mathrm{Lt} \times \mathrm{Wt}, \mathrm{Lt} \times \mathrm{Lo}$, Lt $\times$ Ho, Lt $\times$ Wo, Lo $\times$ Ho and Lo $\times$ Wo. Only data on specimens with total lengths ranging from 120 to $229 \mathrm{~mm}$ were used in these regressions, ensuring the comparisons among models (Zar, 2010).

Relative growth was analyzed by testing the "b" coefficients of each model against the reference values for isometry, beta $=3$ for regressions involving weight $(\mathrm{Lt} \times \mathrm{Wt}, \mathrm{Lt} \times \mathrm{Wo}$ and $\mathrm{Lo} \times \mathrm{Wo})$ and beta $=1$ for regressions involving linear measurements $(\mathrm{Lt} \times \mathrm{Lo}, \mathrm{Lt} \times \mathrm{Ho}$ and Lo $\times \mathrm{Ho}$ ) (Quinn II \& Deriso, 1999). A t-test was used for this analysis (Zar, 2010). Regressions were also compared over time to identify

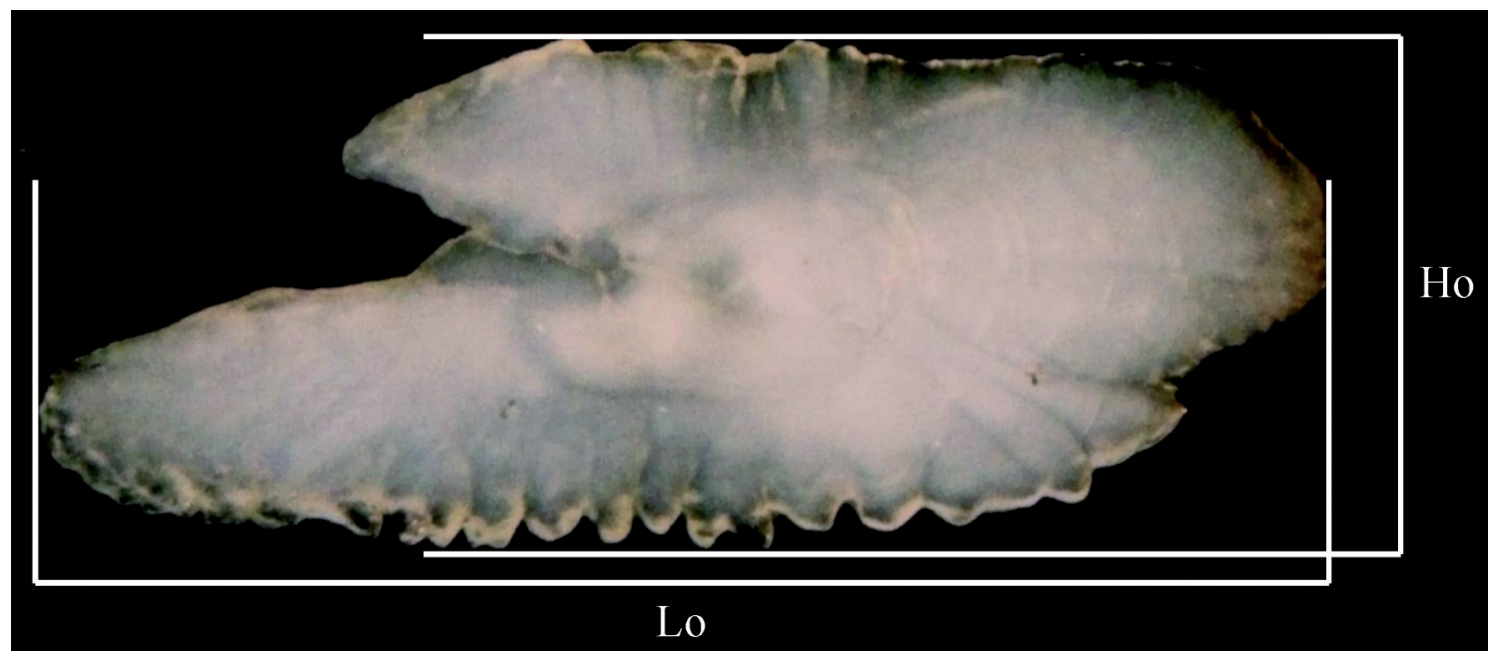

FIGURE 2: Sardinella brasiliensis: sagittal otolith showing axes for otolith length (Lo) and height (Ho) measurements (30x magnification, $\mathrm{Lo}=1.67 \mathrm{~mm}$ ). 
differences among fits, by an analysis of covariance (Sokal \& Rohlf, 1995). The confidence level of 0.95 was adopted in all statistical analysis.

\section{RESULTS}

In 1985, a total of 4,316 individuals of $S$. brasiliensis were sampled, including 1,032 specimens in summer, 1,341 in autumn, 1,053 in winter and 890 in spring. The total length ranged between 66 and $258 \mathrm{~mm}$, with an average (and standard deviation) of $180 \pm 28.05 \mathrm{~mm}$ (Fig. 3A). In 1987, a total of 1,250 individuals were sampled, including 283 in summer, 370 in autumn and 597 in winter. No sampling was performed during the spring of 1987. In 1987, the total length averaged $163 \pm 31.98 \mathrm{~mm}$ and ranged between 75 and $259 \mathrm{~mm}$ (Fig. 3B).
The subsampling procedure resulted in the analysis of 603 otoliths with length ranging between 2.12 and $4.00 \mathrm{~mm}$, height between 0.88 and $1.64 \mathrm{~mm}$ and weight between 0.0004 to 0.0030 g. In 1985 , 350 otoliths presented an average (and standard deviation) length of $3.01 \pm 0.44 \mathrm{~mm}, 1.25 \pm 0.16 \mathrm{~mm}$ in height and $0.0015 \pm 0.0005 \mathrm{~g}$ in weight. Mean values of $1987(\mathrm{n}=253)$ were $3.00 \pm 0.46 \mathrm{~mm}$ in length, $1.23 \pm 0.16$ in height and $0.0014 \pm 0.0006 \mathrm{~g}$ in weight.

A summary of the morphometric analyses, the coefficients of the fitted allometric models and the results of the relative growth analyses is shown in Table 1. Regressions were statistically significant for all of the models ( $\mathrm{P}<0.05$ for all regressions). The coefficient of determination showed acceptable values $\left(0.682<\mathrm{r}^{2}<0.994\right)$ and the residual analyses did not show any trends.
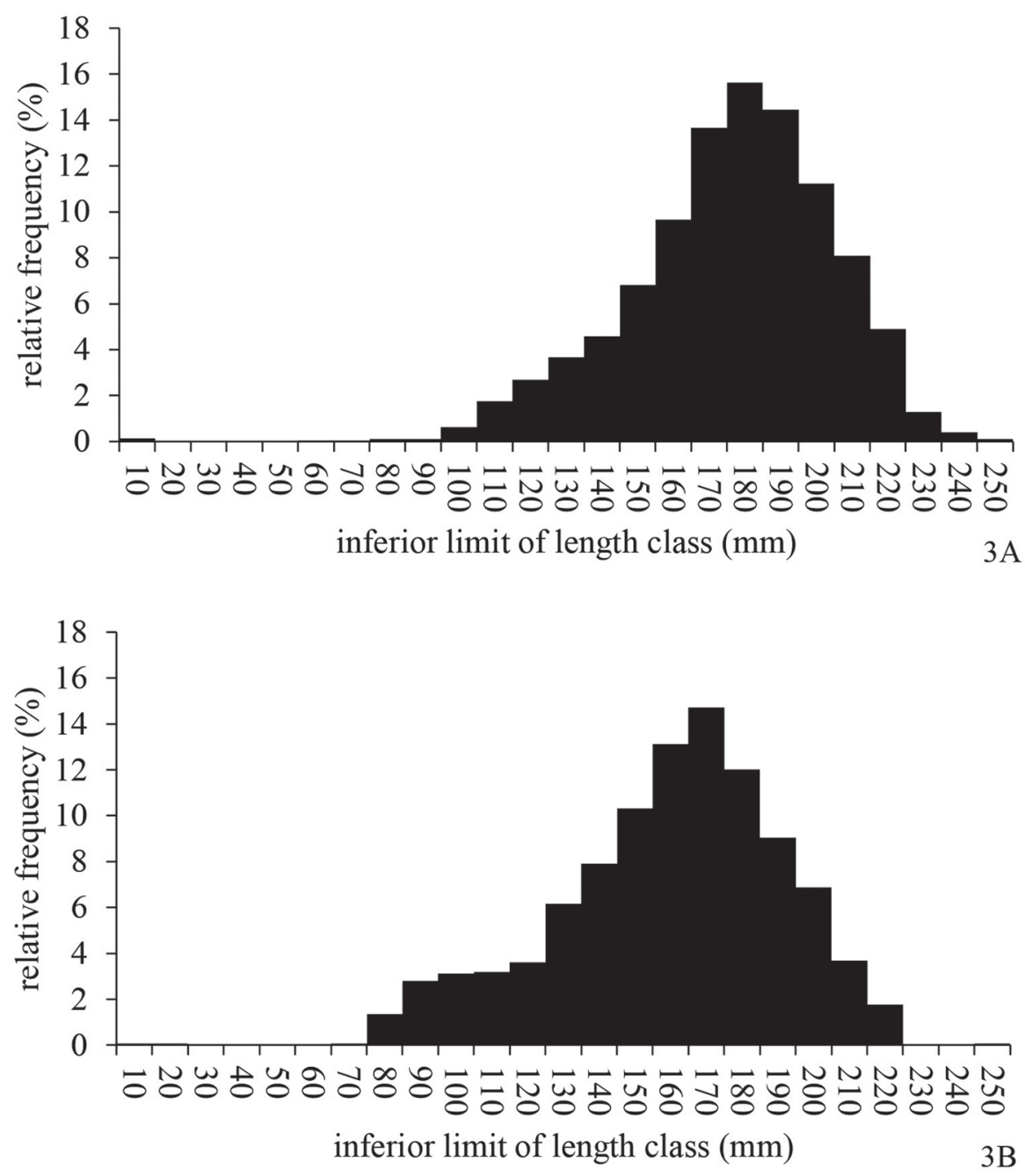

FIGURE 3: Sardinella brasiliensis: length-frequency distributions of specimens sampled in (A) $1985(\mathrm{n}=4,316)$ and $(\mathbf{B}) 1987(\mathrm{n}=1,250)$. 
Comparisons performed among the regressions for both years showed significant differences in all cases (ANCOVA $\mathrm{P}<0.05$ ), generally related to the "b" coefficient, evidencing the acuity of this technique in detecting differences when other sources of variability were eliminated and/or reduced. Higher values of "b" represent higher growth rates, observed mainly in 1987. The fits presented in Table 1 show that in 1987 fishes were heavier and otoliths were longer and higher than in 1985 . Otolith weight varied in a different manner, with heavier sagitta in 1985 . Comments about the results of each relationship are presented below.

Coefficient "b" for the length-weight relationships varied between 2.99 to 3.37 , generally indicating positive allometry, i.e., weight gain was more pronounced. Lower values of "b" and higher values of " $a$ " imply heavier fishes, the opposite being true. These regressions presented the best fits, with the highest $r^{2}$ values (almost one in some cases). In 1985, "b" values presented more remarkable differences than in 1987 , but in all cases these differences were significant $(\mathrm{P}<0.05)$. The highest value of "a" $\left(0.9 \times 10^{-6}\right)$ was registered in the spring of 1985 .

The relationships involving total length and the length and height of otoliths showed high negative allometry, with "b" values lower and not close to 1 . Their values ranged between 0.67 and 0.83 for Lt $\times$ Lo relationships and 0.42 and 0.80 for $\mathrm{Lt} \times$ Ho relationships, gradually decreasing from summer to spring in 1985 and from summer to autumn in 1987. These models showed that increment in total (body) length was proportionally higher than the otolith growth in these two axes, mainly that related to height: sardine is a slender fish and it is not expected a conspicuous growth on this dimension. Besides, it is important to note that lower values of " $b$ " represent lower rates of relative growth ("b" values of regressions involving Ho were lower). The lowest growth in linear measurements (Lo and Ho) was registered in the spring of 1985; growth rates were higher in 1987 than in 1985.

Even considering seasonal variations, both years presented the same pattern mentioned earlier in relation to length-weight relationships, a property of the allometric model applied: lower "b" and higher "a" values result in higher estimates of otolith length and height, the dependent variable $(y)$. This pattern also applies to Lt $\times$ Wo relationships and Lo $\times$ Ho and Lo $\times$ Wo fits of 1985 .

The otolith weight showed high negative allometry relative to total length $(1.25<\mathrm{b}<2.54)$, showing that there is no significant growth in another axis that should has been analyzed (measured), but it was not. If the otoliths had a conspicuous growth in an axis not analyzed (due to its tridimensional growth), Lt $\times$ Wo relationships would revealed this, presenting positive allometry. As commented earlier and contrary to the other analysis, although smaller in terms of linear measurements (Lo, Ho), heavier otoliths were found in 1985 , an indication of more intensive calcification in this year.

In the models of Lo $\times$ Ho and Lo $\times$ Wo, the "b" coefficient ranged between 0.66 and 0.88 and 2.08 and 2.94, respectively, showing a high level of negative allometry. These models revealed the intrinsic pattern of otolith development. Values of "b" also decreased along 1985 and 1987, but the same tendency of relationships was observed: in general, in 1985 allometry was more accentuated than in 1987 , when there were higher rates of growth. These results also confirm that length is the main axis of growth in the otolith of $S$. brasiliensis.

\section{DISCUSSION}

Our results show that morphometric and relative growth analyses represent a suitable tool for understanding the variability of a fish stock. In particular, estimates of " $b$ " values for different periods may vary in the same species, reflecting intrinsic and extrinsic factors influencing the population. RossiWongtschowski et al. (1982) and Vaz-dos-Santos et al. (2010) also analyzed the relative growth of sardine otoliths and, despite differences in the range of total length of the specimens examined by those authors and the present study, the estimates obtained among regressions in each study can indicate patterns of the species.

Rossi-Wongtschowski et al. (1982), studied specimens of Sardinella brasiliensis caught during 1977 and 1978, focusing on geographic differences. Comparisons of our regressions ( $\mathrm{Lt} \times \mathrm{Lo}$ and $\mathrm{Lt} \times \mathrm{Wo}$ ) with those of these authors revealed a tendency of reduction in otolith relative growth in the present study, although its intrinsic pattern (Lo $\times$ Ho and Lo $\times$ Wo) of development was maintained. These results are in accordance with the scenario of the earlier 1980's, when sardine presented a gradual reduction in landing (Cergole \& Dias Neto, 2011).

Contrary to Vaz-dos-Santos et al. (2010) that showed a reduction in relative growth of Sardinella brasiliensis during January-February (based on data from 2008), the results of the present study showed a decrease in relative growth of the species during spring (October to December) in all variables investigated. This difference may be related with reproduction 
TABLE 1: Sardinella brasiliensis: regression analyses ("a" and "b" regression coefficients of allometric model, $\mathrm{r}^{2}=$ coefficient of determination) and relative growth analysis (" $\mathrm{t}$ " = t-test statistic, $\mathrm{P}=$ probability value of $\mathrm{t}$-test, $\mathrm{n}=$ number of observations) by year and season ( $\mathrm{Su}=$ Summer, Au = Autumn, Wi = Winter, $\mathrm{Sp}=$ Spring). Lt and Wt are length and weight of specimens, respectively. Lo, Ho and Wo are otolith length, height and weight, respectively.

\begin{tabular}{|c|c|c|c|c|c|c|c|c|}
\hline \multirow{2}{*}{ Variables } & \multirow{2}{*}{ Year } & \multirow{2}{*}{ Season } & \multicolumn{3}{|c|}{ Allometric model } & \multicolumn{2}{|c|}{ Relative Growth } & \multirow{2}{*}{$\mathbf{n}$} \\
\hline & & & $\mathbf{a}$ & $\mathbf{b}$ & $\mathbf{r}^{2}$ & "t" & $\mathbf{P}$ & \\
\hline \multirow[t]{7}{*}{$\mathrm{Lt} \times \mathrm{Wt}$} & 1985 & $\mathrm{Su}$ & $0.1 \times 10^{-6}$ & 3.37 & 0.990 & 10.02 & $<0.05$ & 88 \\
\hline & & $\mathrm{Au}$ & $0.2 \times 10^{-6}$ & 3.25 & 0.986 & 6.16 & $<0.05$ & 88 \\
\hline & & Wi & $0.3 \times 10^{-6}$ & 3.17 & 0.981 & 3.58 & $<0.05$ & 87 \\
\hline & & $S p$ & $0.9 \times 10^{-6}$ & 2.99 & 0.958 & -0.18 & 0.43 & 87 \\
\hline & 1987 & $\mathrm{Su}$ & $0.3 \times 10^{-6}$ & 3.20 & 0.994 & 7.11 & $<0.05$ & 88 \\
\hline & & $\mathrm{Au}$ & $0.2 \times 10^{-6}$ & 3.24 & 0.991 & 7.24 & $<0.05$ & 88 \\
\hline & & Wi & $0.2 \times 10^{-6}$ & 3.26 & 0.983 & 5.17 & $<0.05$ & 77 \\
\hline \multirow[t]{7}{*}{ Lt $\times$ Lo } & 1985 & $\mathrm{Su}$ & 0.0430 & 0.82 & 0.907 & -6.18 & $<0.05$ & 85 \\
\hline & & $\mathrm{Au}$ & 0.0506 & 0.79 & 0.912 & -7.86 & $<0.05$ & 87 \\
\hline & & Wi & 0.0508 & 0.79 & 0.938 & -9.08 & $<0.05$ & 81 \\
\hline & & $S p$ & 0.0935 & 0.67 & 0.893 & -12.57 & $<0.05$ & 81 \\
\hline & 1987 & $\mathrm{Su}$ & 0.0414 & 0.83 & 0.939 & -0.03 & 0.49 & 81 \\
\hline & & $\mathrm{Au}$ & 0.0445 & 0.82 & 0.952 & -9.08 & $<0.05$ & 86 \\
\hline & & Wi & 0.0543 & 0.78 & 0.943 & -9.89 & $<0.05$ & 74 \\
\hline \multirow[t]{7}{*}{$\mathrm{Lt} \times \mathrm{Ho}$} & 1985 & $\mathrm{Su}$ & 0.0200 & 0.80 & 0.859 & -5.82 & $<0.05$ & 87 \\
\hline & & $\mathrm{Au}$ & 0.0540 & 0.61 & 0.810 & -12.14 & $<0.05$ & 83 \\
\hline & & Wi & 0.0767 & 0.54 & 0.816 & -16.07 & $<0.05$ & 84 \\
\hline & & $S p$ & 0.1441 & 0.42 & 0.709 & -19.40 & $<0.05$ & 83 \\
\hline & 1987 & $\mathrm{Su}$ & 0.0270 & 0.74 & 0.889 & -8.66 & $<0.05$ & 80 \\
\hline & & $\mathrm{Au}$ & 0.0392 & 0.67 & 0.863 & -11.42 & $<0.05$ & 88 \\
\hline & & Wi & 0.0603 & 0.59 & 0.892 & -17.11 & $<0.05$ & 73 \\
\hline \multirow[t]{7}{*}{$\mathrm{Lt} \times \mathrm{Wo}_{\mathrm{o}}$} & 1985 & $\mathrm{Su}$ & $0.3 \times 10^{-9}$ & 2.54 & 0.826 & -3.45 & $<0.05$ & 79 \\
\hline & & $\mathrm{Au}$ & $0.9 \times 10^{-8}$ & 1.86 & 0.831 & -11.79 & $<0.05$ & 77 \\
\hline & & Wi & $0.1 \times 10^{-7}$ & 1.80 & 0.895 & -17.25 & $<0.05$ & 81 \\
\hline & & $S p$ & $0.2 \times 10^{-6}$ & 1.25 & 0.682 & -18.80 & $<0.05$ & 85 \\
\hline & 1987 & $\mathrm{Su}$ & $0.1 \times 10^{-8}$ & 2.26 & 0.913 & -9.21 & $<0.05$ & 79 \\
\hline & & $\mathrm{Au}$ & $0.1 \times 10^{-8}$ & 2.25 & 0.877 & -8.24 & $<0.05$ & 87 \\
\hline & & Wi & $0.3 \times 10^{-8}$ & 2.07 & 0.901 & -11.32 & $<0.05$ & 71 \\
\hline \multirow[t]{7}{*}{$\mathrm{Lo} \times \mathrm{Ho}$} & 1985 & $\mathrm{Su}$ & 0.4657 & 0.88 & 0.813 & -2.64 & $<0.05$ & 87 \\
\hline & & $\mathrm{Au}$ & 0.5290 & 0.77 & 0.833 & -6.19 & $<0.05$ & 84 \\
\hline & & Wi & 0.5957 & 0.68 & 0.856 & -10.12 & $<0.05$ & 82 \\
\hline & & $\mathrm{Sp}$ & 0.6112 & 0.66 & 0.808 & -9.58 & $<0.05$ & 82 \\
\hline & 1987 & $\mathrm{Su}$ & 0.4836 & 0.86 & 0.876 & -58.81 & $<0.05$ & 81 \\
\hline & & $\mathrm{Au}$ & 0.3610 & 0.82 & 0.891 & -5.81 & $<0.05$ & 86 \\
\hline & & Wi & 0.5571 & 0.73 & 0.882 & -8.36 & $<0.05$ & 72 \\
\hline \multirow[t]{7}{*}{ Lo $\times$ Wo } & 1985 & $\mathrm{Su}$ & $0.5 \times 10^{-5}$ & 2.94 & 0.847 & -0.42 & 0.33 & 81 \\
\hline & & $\mathrm{Au}$ & $0.1 \times 10^{-4}$ & 2.41 & 0.883 & -5.74 & $<0.05$ & 76 \\
\hline & & Wi & $0.1 \times 10^{-4}$ & 2.27 & 0.929 & -10.35 & $<0.05$ & 81 \\
\hline & & $S p$ & $0.2 \times 10^{-4}$ & 2.08 & 0.870 & -10.20 & $<0.05$ & 81 \\
\hline & 1987 & $\mathrm{Su}$ & $0.7 \times 10^{-5}$ & 2.70 & 0.905 & -3.02 & $<0.05$ & 80 \\
\hline & & $\mathrm{Au}$ & $0.6 \times 10^{-5}$ & 2.78 & 0.926 & -2.50 & $<0.05$ & 81 \\
\hline & & Wi & $0.9 \times 10^{-5}$ & 2.45 & 0.872 & -5.00 & $<0.05$ & 75 \\
\hline
\end{tabular}

since the spawning peak of $S$. brasiliensis occurs during spring, continuing in the summer ( $c f$. Cergole \& Dias Neto, 2011). Although "b" values typically decrease during spring, the values of the coefficient "a" increase. This outcome is not simply a mathematical effect, as previously suggested by Braga (1997), but reflects the life cycle of the species, as showed in the results and discussed as follow.
Our results also show that there is an increase in individual weight resulting from gonad maturation (Braga, 1997), also documented for Sardinella brasiliensis by several authors (Vazzoler \& RossiWongtschowski, 1976; Rossi-Wongtschowski, 1977; Isaac-Nahum et al., 1983, 1988; Matsuura et al., 1992, Matsuura, 1998). The coefficient "a" can be identified as the allometric condition factor (Braga, 
1986; 1997), reflecting the welfare of the stock, and is consistent with an increase in their values during the year in the summer and in the spring. The condition factor is sensitive to seasonal oscillations (Bolger \& Connolly, 1989). The simultaneous decrease of the "b" values indicates a proportional decrease in somatic growth (once "b" is a growth rate), supported by age and growth studies, because one period of ring formation in otoliths is November-December, a period also related to spawning (Saccardo et al., 1988).

These comments can be also applied to the relationships between total length and otolith measurements. As demonstrated by our results, higher "b" values are related to smaller otoliths, which are present in the summer, when an additional ring forms in the otoliths in association with the extensive spawning that began in the spring (Saccardo et al., 1988). As only one cohort is produced per year, adult ring formation in otoliths is related to the beginning and to the end of the spawning peak (Cergole \& Valentini, 1994).

Regressions between otolith measurements describe the development of the otolith. Sardines, including S. brasiliensis, have a long, slender body. Otolith development reflects this pattern. The growth of the otolith in length is more pronounced than in height, consistent with the body shape. The morphology of the sardine sagitta also confirms this pattern (Lemos et al., 1995).

Food availability also plays a role in the life cycle of S. brasiliensis. It has been known since the 1950's that this species is a suspension feeder that eats phytoplankton (diatoms, dinoflagellates) and zooplankton (copepods) (Montes, 1953). The diet varies according to prey availability, which is conditioned by area and season (Goitein, 1978; Schneider \& Schwingel, 1999; Kurtz \& Matsuura, 2001). The productivity of the SEBB affects the development of the fish, primarily in the larval phase (Matsuura, 1996; Jablonski \& Legey, 2004, 2005; Gigliotti et al., 2010, Moraes et al., 2012). Productivity is more pronounced primarily during spring and summer, consistent with our results and environmental conditions (CARTONGIESE SODA, 2013).

Given that the population dynamics of $S$. brasiliensis explains the variation in morphometry and in the pattern of relative growth, how are these effects expressed by the entire stock? Literature on the theme allows describing the following scenario of 1980's:

The sardine stock was in equilibrium in 1985, as stated by Cergole (1995) based on virtual population analysis (VPA, sensu Sparre \& Venema, 1998). According to Cergole (1995) a period of decline (collapse) of the sardine stock began in 1986 and continued until
1990. Matsuura et al. (1992) also report high mortality rates of sardine larvae in 1986. The collapse of the stock in 1987, caused by environmental features and overfishing, resulted in decreased recruitment (Matsuura, 1998; Schwartzlose et al., 1999). Biomass in 1985 was estimated at 776,000 t and spawning biomass at $317,000 \mathrm{t}$. In 1987, these values were 400,000 t and 177,000 t, respectively (Cergole et al., 2002). During these two years, the total landings were 123,961 and $91,797 \mathrm{t}$, respectively.

All of these factors affect individual body length and weight (Wootton, 1998; Cergole et al., 2002) and consequently, otolith development, as demonstrated here. The models fitted for both study periods illustrate these patterns of variation. It is well known that a decrease in total biomass increases the availability of food per individual, favoring individual development. In 1987, the length-weight relationships showed that the fish were heavier and that the otoliths were growing more rapidly than in 1985, clearly indicating the results of the decrease in the stock. Remaining as a conjecture, this fact would explain the otolith weight variations in both years: a fast growth (in 1987) would imply in a less rate of calcification. But this is a hypothesis for another study.

In this study the biological plasticity of Sardinella brasiliensis was reinforced. Such plasticity, shown by the species over a short period of time, is well known and it has also been detected in the form of a recent decrease in the length at first maturation and an earlier initiation of spawning (Cergole \& Dias Neto, 2011).

Morphometry and relative growth are useful for monitoring the sardine in the SEBB, given that our results show that the development of the body and the otolith accompany changes in the other indicators of stock health. Moreover, these methodologies are easy, inexpensive, rapid and practical to apply.

\section{CONCLUSIONS}

The present study showed that morphometry and relative growth are highly efficient tools for monitoring S. brasiliensis. The use of historical data related to two distinct phases of the stock (equilibrium in 1985 and collapse in 1987) identified a pattern that can serve as a reference for the species. Life cycle of sardine affects and explains seasonal and inter-annual variations in the attributes analyzed. It is recommended that the same protocol applied here (total length range, number of individuals) be used for other comparisons, allowing a proper diagnosis of the status of the stock of $S$. brasiliensis in the area. 


\section{RESUMO}

A sardinha-verdadeira, Sardinella brasiliensis, é um pequeno clupeídeo pelágico distribuido entre $22^{\circ} \mathrm{S}$ e $29^{\circ} \mathrm{S}$, onde forma grandes cardumes. É um importante recurso pesqueiro capturado pelas frotas de cerco (traineiras) atuantes nesta área. Embora seja uma espécie amplamente estudada sob vários aspectos, poucos são os estudos que tratam de morfometria e crescimento relativo. O objetivo do presente estudo foi analisar o crescimento relativo com base em morfometria corporal e de otólitos, identificando padröes e caracterizando a população. Amostragens mensais foram realizadas em 1985 e 1987, sendo obtidos dados de comprimento total, peso e comprimento, altura e peso de otólitos. Estes dados foram analisados com a aplicaçấo do modelo alométrico de Huxley $\left(y=a x^{b}\right)$, sazonalmente e em cada ano, sendo as regressóes obtidas comparadas entre si. O coeficiente " $b$ " foi testado (teste t) quanto à isometrialalometria. Um total de 603 exemplares com comprimento total entre $120 \mathrm{~mm}$ e $229 \mathrm{~mm}$ foi analisado. As relaçóes comprimento-peso tenderam a apresentar alometria positiva, enquanto que as relaçóes entre o comprimento total e as medidas dos otólitos tenderam à alometria negativa. As taxas de crescimento relativo diminuiram ao longo do ano, com os menores valores na primavera, quando há o pico de desova da espécie. Em contrapartida, o fator de condição (coeficiente " $a$ " dos modelos alométricos) aumentou paulatinamente até a primavera, consequência do ganho de peso em função da maturação gonadal. Comparaçôes realizadas entre 1985 e 1987 mostram que o crescimento foi mais rápido durante o periodo de colapso do estoque, em 1987. A metodologia utilizada permitiu a deteç̧ão destas variaçóes. Neste estudo foi estabelecido um padrão histórico para o crescimento relativo da sardinha-verdadeira, evidenciando que as técnicas empregadas são úteis para avaliar a espécie na área de estudo.

Palavras-Chave: Otólitos; Sagitta; Modelo alométrico; Condiçáo populacional.

\section{ACKNOWLEDGMENTS}

This paper was written in honor of Dr. José Lima de Figueiredo. The authors express their gratitude to: Dr. Mônica de Toledo-Piza Ragazzo for the opportunity and Drs. Maria Cristina Cergole and Suzana Anita Saccardo for the data and materials. We thank Sr. André Hahne and his staff for their pleasant assistance and laboratory support. We also thank Universidade São Judas Tadeu for the award of a scholarship for scientific initiation to the first author.

\section{REFERENCES}

Aguirre, W.E. 2003. Allometric growth of the sulcus in Cynoscion spp. (Sciaenidae). Journal of Fish Biology, 63(5): 1341-1346.

Bervian, G.; Fontoura, N.F. \& Haimovici, M. 2006. Statistical model of variable allometric growth: otolith growth in Micropogonias furnieri (Actinopterygii, Sciaenidae). Journal of Fish Biology, 68: 196-208.

Bolger, T. \& Connolly, P.L. 1989. The selection of suitable indices for the measurement and analysis of fish indices for the measurement and analysis of fish condition. Journal of Fish Biology, 34(2): 171-182.

Braga, E.S. \& Niencheski, L.F.H. 2006. Composição das massas de água e seus potenciais produtivos na área entre o Cabo de São Tomé (RJ) e o Chuí (RS). In: Rossi-Wongtschowski, C.L.D.B. \& Madureira L.S.P. $O$ ambiente oceanográfico da plataforma continental e do talude na região Sudeste-Sul do Brasil. São Paulo, EDUSP. p. 161-218.

Braga, F.M.S. 1982. Estudo do crescimento relativo de Sardinella brasiliensis (Steindachner, 1879), na área entre Macaé (22 $23^{\circ} \mathrm{S}$ ) e sul da Ilha de Santa Catarina (27 35'S). (Tese de Doutorado). São Paulo, Instituto Oceanográfico da Universidade de São Paulo.

BragA, F.M.S. 1986. Estudo entre fator de condição e relação peso/ comprimento para alguns peixes marinhos. Revista Brasileira de Biologia, 46(2): 339-346.

Braga, F.M.S. 1987. Estudo da diversidade de Sardinella brasiliensis (Steindachner, 1879) na área entre Macaé (22²3’S) e Ilha de Santa Catarina $\left(27^{\circ} 35^{\prime}\right.$ S). 1. Crescimento e dimensôes corporais. Revista Brasileira de Zoologia, 4(3): 235-250.

Braga, F.M.S. 1997. Análise da equação alométrica na relação peso e comprimento e o fator de condição em Plagioscion squamosissimus (Teleostei, Sciaenidae). Revista Brasileira de Biologia, 57(3): 417-425.

Cadrin, S.X. \& Friedland, K.D. 1999. The utility of image processing techniques for morphometric analysis and stock identication. Fisheries Research, 43: 129-139.

Campana, S.E. 2001. Accuracy, precision and quality control in age determination, including a review of the use and abuse of age validation methods. Journal of Fish Biology, 59: 197-242.

CARTON-GIESE SODA VERSION 2.0.2-4: Oceanic and air-sea interface data from the UMD Simple Ocean Data Assimilation Reanalysis. Disponível em: <http://iridl.ldeo.columbia.edu/ SOURCES/.CARTON-GIESE/.SODA/.v2p0p2-4>. Acesso em: 20/09/2013.

Casselman, J.M. 1990. Growth and relative size of calcified structures of fish. Transactions of the American Fisheries Society, 119(4): 673-688.

Castro, B.M.; Lorenzetti, J.A.; Silveira, I.C.A. \& Miranda, L.B. 2006. Estrutura termohalina e circulação na região entre o Cabo de São Tomé (RJ) e o Chuí (RS). In: RossiWongtschowski, C.L.D.B. \& Madureira, L.S.P. (Eds.). O ambiente oceanográfico da Plataforma Continental e do Talude na regiāo Sudeste-Sul do Brasil. São Paulo, EDUSP. p. 11-120.

Cergole, M.C. 1995. Stock assessment of the Brazilian Sardine, Sardinella brasiliensis, of the Southeastern Coast of Brazil. Scientia Marina, 59(3-4): 597-610.

Cergole, M.C. \& Dias-Neto, J. 2011. Plano de gestão para o uso sustentável da sardinha-verdadeira Sardinella brasiliensis no Brasil. Brasília, IBAMA.

Cergole, M.C. \& Rossi-Wongtschowski, C.L.D.B. 2005. Sardinella brasiliensis. In: Cergole, M.C.; Ávila-da-Silva, A.O. \& Rossi-Wongtschowski, C.L.D.B. Análise das principais pescarias comerciais da regiāo Sudeste-Sul: dinâmica das principais 
espécies em explotação. São Paulo, Instituto Oceanográfico da Universidade de São Paulo. p. 145-150.

Cergole, M.C. \& Valentini, H. 1994. Growth and mortality estimates of Sardinella brasiliensis in the Southeastern Brazilian Bight. Boletim do Instituto Oceanográfico, 42(1/2): 113-127.

Cergole, M.C.; Saccardo, S.A. \& Rossi-Wongtschowski, C.L.D.B. 2002. Fluctuations in the spawning and recruitment of the Brazilian sardine: 1977-1997. Revista Brasileira de Oceanografia, 50: 13-26.

Checkley Jr.; D.; Alheit, J.; Oozeki, Y.\& Roy, C. 2009. Climate change and small pelagic fish. Cambridge Cambridge, University Press,

Dallagnolo, R.; Schwingel, P.R. \& Perez, J.A.A. 2010. Estimativas de produção anual de sardinha-verdadeira (Sardinella brasiliensis) em Santa Catarina: um modelo de projeção de capturas a partir dos padrốes mensais de desembarque no Estado. Brazilian Journal of Aquatic Science and Technology, 14(2): 95-104.

Figueiredo, J.L. \& Menezes, N.A. 1978. Manual de peixes marinhos do sudeste do Brasil. II. Teleostei (1). Sáo Paulo, Museu de Zoologia da Universidade de São Paulo.

Fonteles-Filho, A.A.; Ximenes-Carvalho, M.O.; Paiva, M.P. \& Petrere Júnior, M. 2005. Age and growth of Brazilian sardinella Sardinella brasiliensis (Steindachner) (Osteichthyes: Clupeidae) in the Southeastern Brazil. Arquivos de Ciências do Mar, 38: 39-47.

FURG. 2010. Mapeamento e estimativa de biomassa na área de ocorrência da sardinha-verdadeira (Sardinella brasiliensis) através de metodologia hidroacústica (Cruzeiro ECOSAR VII). Rio Grande/Itajaí, FURG/Instituto Chico Mendes de Conservação da Biodiversidade.

GEP/UNIVALI. 2013. Estatística Pesqueira Industrial de Santa Catarina. Disponível em: <http://siaiacad04.univali.br/ consulta>. Acesso em: 07/01/2013.

Gigliotti, E.S.; Gherardi D.F.M.; Paes, E.T.; Souza, R.B. \& Katsuragawa, M. 2010. Spatial analysis of egg distribution and geographic changes in the spawning habitat of the Brazilian sardine Sardinella brasiliensis. Journal of Fisheries Biology, 77(10): 2248-2267.

Goitein, R. 1978. Sardinella brasiliensis (Steindachner, 1879): estudos sobre alimentação nas regióes de Ubatuba (23⒉ e Santos $\left(24^{\circ} 02^{\prime} S\right)$. (Dissertação de Mestrado). São Paulo, Instituto Oceanográfico da Universidade de São Paulo.

Gomiero, L.M. \& Braga, F.M.S. 2007. Descriçâao dos otólitos de tucunarés (Cichla sp. e Cichla monoculus) no reservatório da hidrelétrica de Volta Grande (SP-MG). Ciência Animal Brasileira, 8(1): 119-126.

Hunt, J.J. 1992. Morphological characteristics of otoliths for selected fish in the Northwest Atlantic. Journal of Northwest Atlantic Fishery Science, 13: 63-75.

Huxley, J.S. 1993. Problems of relative growth; with a new introduction. Baltimore, The John Hopkins University Press.

Instituto de Pesca. 2013. Estatística Pesqueira On-line. Disponível em: <www.pesca.sp.gov.br/estatistica/index.php>. Acesso em: 07/01/2013.

IsaAC-Nahum, V.J.; Cardoso, R.D.; Servo, G.J.M. \& RossiWongtschowski, C.L.D.B. 1988. Aspects of the spawning biology of the Brazilian sardine, Sardinella brasiliensis (Steindachner, 1879), (Clupeidae). Journal of Fish Biology, 32(3): 383-396.

Isaac-Nahum, V.J.; Vazzoler, A.E.A.M. \& Zaneti-Prado, E.M. 1983. Estudos sobre a estrutura, ciclo de vida e comportamento de Sardinella brasiliensis (Steindachner, 1879), na área entre $22^{\circ} \mathrm{S}$ e $28^{\circ} \mathrm{S}$, Brasil. 3 - Morfologia e histologia de ovários e escala de maturidade. Boletim do Instituto Oceanográfico, 32(1): $1-16$
Jablonski, S. \& LegeY, L.F.L. 2004. Quantifying environmental effects on the recruitment of Brazilian sardine (Sardinella brasiliensis), 1977-1993. Scientia Marina, 68(3): 385-398.

Jablonski, S. \& Legey, L.F.L. 2005. Towards the development of an environmental rule-based model for predicting recruitment in Brazilian sardine Sardinella brasiliensis. African Journal of Marine Science, 27(3): 539-547.

Kerstan, M. 2000. Estimation of precise ages from the marginal increments widths of differently growing sardine (Sardine sagax) otoliths. Fisheries Research, 46: 207-225.

Kristoffersen, J.B. 2007. Growth rate and relative otolith size in populations of adult Müller's pearlside Maurolicus muelleri. Journal of Fish Biology, 71(5): 1317-1330.

Kurtz, F.W. \& Matsuura, Y. 2001. Food and feeding ecology of Brazilian sardine (Sardinella brasiliensis) from the southeastern Brazilian Bight. Revista Brasileira de Oceanografia, 49(1/2): 61-74.

Lemos, P.H.B.; CorrêA, M.F.M \& Pinheiro, P.C. 1995. Catálogo de otólitos de Clupeidae (Clupeiformes - Osteichthyes) do litoral do Estado do Paraná, Brasil. Arquivos de Biologia e Tecnologia, 38(3): 747-759.

Lidster, W.W.; Lilly, G.R. \& Dawe, E.G. 1994. Otoliths of Arctic cod (Boreogadus saida), small Atlantic cod (Gadus morhua), and three other fish species from Newfoundland Waters: description and relationship of body length to otolith length. Journal of Northwest Atlantic Fishery Science, 16: 33-40.

LizAmA, M.A.P \& TAKEмото, R.M. 2000. Relação entre o padrão de crescimento em peixes e as diferentes categorias tróficas: uma hipótese a ser testada. Acta Scientiarum, 22(2): 455-463.

Lombarte, A. \& Lleonart, J. 1993. Otolith size changes related with body growth, habitat depth and temperature. Environmental Biology of Fishes, 37(3): 297-306.

Lorenzo, M.I.; VAZ-DOs-SANTOS, A.M. \& Rossi-WongtschowsKI, C.L.D.B. 2011. Growth pattern of the young of the year Argentine hake Merluccius hubbsi Marini, 1933 (Gadiformes Merluccidae) along the Brazilian and Uruguayan coasts. Environmental Biology of Fishes, 91(2): 155-164.

Matsuura, Y. 1986. Contribuição ao estudo da estrutura oceanográfica da regiáo Sudeste entre o Cabo Frio (RJ) e o Cabo de Santa Marta Grande (SC). Ciência e Cultura, 38(8): 1439-1450.

MatsunRA, Y. 1996. A probable cause of recruitment failure of the Brazilian Sardine Sardinella aurita population during 1974/1975 spawning season. South African Journal of Marine Science, 17: 29-35.

Matsuura, Y. 1998. Brazilian sardine (Sardinella brasiliensis) spawing in the Southeast Brazilian bright over the period 1976-1993. Revista Brasileira de Oceanografia, 46(1): 33-43.

Matsuura, Y.; Spach, H.L. \& Katsuragawa, M. 1992. Comparision of spawning patterns of the Brazilian sardine (Sardinella brasiliensis) and anchoita (Engraulis anchoita) in Ubatuba region, southern Brazil during 1985 through 1989. Boletim do Instituto Oceanográfico, 40(1/2): 101-115.

Megalofonou, P. 2006. Comparison of otolith growth and morphology with somatic growth and age in young-of-theyear bluefin tuna. Journal of Fish Biology, 68(6): 1867-1878.

Monteiro, L.R.; Di Beneditto, A.P.M.; Guillermo, L.H. \& Rivera, L.A. 2005. Allometric changes and shape differentiation of sagitta otoliths in sciaenid fishes. Fisheries Research, 74(1-3): 288-299.

Montes, M.L.A. 1953. Nota sobre alimentação de alevinos da sardinha-legítima ou verdadeira Sardinella aurita Cuvier \& Valenciennes. Boletim do Instituto Oceanográfico, 6(1-2): 161-180.

Moraes, L.E.D.S.; Gherardi, D.F.M.; Katsuragawa, M. \& PAES, E.T. 2012. Brazilian sardine (Sardinella brasiliensis 
Steindachner, 1879) spawning and nursery habitats: spatial-scale partitioning and multiscale relationships with thermohaline descriptors. ICES Journal of Marine Science, 69(6): 939-952.

Quinn II, T.J. \& Deriso, R.B. 1999. Quantitative fish dynamics. New York, Oxford University Press.

RICKeR, W.E. 1975. Computation and interpretation of biological statistics of fish populations. Bulletin of the Fisheries Research Board of Canada, 191: 1-382.

Rossi-Wongtschowski, C.L.D.B. 1977. Estudo das variações da relação peso total/comprimento total em função do ciclo reprodutivo e comportamental de Sardinella brasiliensis (Steindachner, 1879) da costa brasileira entre $23^{\circ} \mathrm{S}$ e $28^{\circ} \mathrm{S}$. Boletim do Instituto Oceanográfico, 26: 131-180.

Rossi-Wongtschowski, C.L.D.B.; Saccardo, S.A. \& Vazzoler, A.E.A.M. 1991. Características biológicas dos cardumes de sardinha e relaçáo com as condiçōes oceanográficas na região sudeste do Brasil (outubro-novembro/1988). Publicação especial do Instituto Oceanográfico, 8: 1-39.

Rossi-Wongtschowski， C.L.D.B.; Vaz-Dos-SAntos, A.M.; Costa, M.R.; Figueiredo, J.L.; Ávila-da-Silva, A.O.; Moura, R.L. \& Menezes, N.A. 2009. Peixes Marinhos. In: Bressan, P.M.; Kierulff, M.C.M. \& Sugieda, A.M. (Org.). Fauna ameaçada de extinção no Estado de São Paulo: Vertebrados. São Paulo, Fundação Parque Zoológico de São Paulo/SMA. p. 425-568.

Rossi-Wongtschowski, C.L.D.B.; VAzzoler, A.E.A.M. \& Braga, F.M.S. 1982. Estudos sobre estrutura, ciclo de vida e comportamento de Sardinella brasiliensis (Steindachner, 1879), na área entre $22^{\circ} \mathrm{S}$ e $28^{\circ} \mathrm{S}$, Brasil. I. Morfologia dos otólitos. Boletim do Instituto Oceanográfico, 31(2): 57-76.

SACCARDO, S.A. \& IsAac-NAHUM, V.J. 1985. Biologia e disponibilidade de sardinha (Sardinella brasiliensis) na costa Sudeste do Brasil. PDP/SUDEPE Série Documentos Técnicos, 33: 265-294.

Saccardo, S.A.; Rossi-Wongtschowski, C.L.D.B.; Cergole, M.C. \& Bittencourt, M.M. 1988. Age and growth of the Southern Brazilian Sardine, Sardinella brasiliensis, 1981-1983. Boletim do Instituto Oceanográfico, 36: 17-35.

Schneider, F. \& Schwingel, P.R. 1999. Estudo preliminar da ecologia trófica da Sardinella brasiliensis na costa sudeste do Brasil. Notas Técnicas da Facimar, 3: 67-72.

Schwartzlose, R.A.; Alheit, J.; Bakun, A.; Baumgartner, T.R.; Cloete, R.; Crawford, R.J.M.; Fletcher, W.J.; GreenRuiz, Y.; Hagen, E.; KaWasaKi, T.; Lluch-Belda, D.; LluchCota, S.E.;. MacCall, A.D.; Matsuura, Y.; NevarezMartinez, M.O.; Parrish, R.H.; Roy, C.; Serra, R.; Shust, K.V.; WARD, M.N. \& ZuZunAGA, J.Z. 1999. Worldwide largescale fluctuations of sardine and anchovy populations. South African Journal of Marine Science, 21: 289-347.

Sokal, R.R. \& RohlF, F.J. 1995. Biometry. New York, W.H. Freeman and Company.

Sparre, P. \& Venema, S.C. 1998. Introduction to tropical fish stock assessment - part 1: manual. FAO Fisheries Technical Paper, 306(1): 1-407.

Strelcheck, A.J.; Fitzhugh, G.R.; Coleman, F.C. \& Koenig, C.C. 2003. Otolith-fish size relationship in juvenile gag (Mycteroperca microlepis) of the eastern Gulf of Mexico: a comparison of growth rates between laboratory and field populations. Fisheries Research, 60(2-3): 255-265.
Swain, D.P. \& Foote, C.J. 1999. Stocks and chameleons: the use of phenotypic variation in stock identification, Fisheries Research, 43: 113-128.

Tuset, V.M.; Lozano, I.J.; González, J.A.; Pertusa, J.F. \& García-Díaz, M.M. 2003. Shape indices to identify regional differences in otolith morphology of comber, Serranus cabrilla (L., 1758). Journal of Applied Ichthyology, 19: 88-93.

Vaz-dos-Santos, A.M. \& Rossi-Wongtschowski, C.L.D.B. 2013. Length-weight relationships of the ichthyofauna associated with the Brazilian sardine, Sardinella brasiliensis, on the Southeastern Brazilian Bight $\left(22^{\circ} \mathrm{S}-29^{\circ} \mathrm{S}\right)$ between 2008 and 2010. Biota Neotropica, 13(2): 326-330.

Vaz-dos-Santos, A.M.; Alleman, M.M.; Rossi-Wongtschoski, C.L.D.B.; Cergole, M.C. \& Saccardo, S.A. 2010. Uso de otólitos para estudo do crescimento relativo da sardinhaverdadeira Sardinella brasiliensis (Steindachner, 1879) na regiāo Sudeste/Sul do Brasil $\left(22^{\circ} \mathrm{S}\right.$ e $\left.29^{\circ} \mathrm{S}\right)$. In: Congresso Brasileiro de Oceanografia, 4º Rio Grande. Anais. Rio Grande, AOCEANO, p. 636-638.

VAZ-dos-Santos, A.M.; SAntos-CruZ, N.N. \& RossiWongtschowsKi, C.L.D.B. 2007. Caracterização dos otólitos sagitta do peixe-lagarto Bembrops heterurus Miranda-Ribeiro, 1903 (Teleostei: Percophidae) da região Sudeste-Sul do Brasil. Bioikos, 21(1): 69-78.

Vazzoler, A.E.A.M. \& Rossi-Wongtschowski, C.L.D.B. 1976. Sardinella brasiliensis: tipo de desova, fecundidade e potencial reprodutivo. I. Área entre $23^{\circ} 40^{\prime} \mathrm{S}$ e $24^{\circ} 20^{\prime} \mathrm{S}$, Brasil. Boletim do Instituto Oceanográfico, 25: 131-155.

VAzzoler, A.E.A.M.; Rossi-Wongtschowski, C.L.D.B. \& BRAGA, F.M.S. 1982. Estudos sobre estrutura, ciclo de vida e comportamento de Sardinella brasiliensis (Steindachner, 1879), na área entre $22^{\circ} \mathrm{S}$ e $28^{\circ} \mathrm{S}$, Brasil. II. Idade individual e crescimento dos otólitos. Boletim do Instituto Oceanográfico, 31(2): 77-84.

VAzzoler, A.E.A.M.; Rossi-Wongtschowski, C.L.D.B. \& BRAGA, F.M.S. 1987. Estudos sobre estrutura, ciclo de vida e comportamento de Sardinella brasiliensis (Steindachner, 1879), na área entre $22^{\circ} \mathrm{S}$ e $28^{\circ} \mathrm{S}$, Brasil 4. Crescimento: aspectos quantitativos. Boletim do Instituto Oceanográfico, 35(1): 53-63.

Vieira, S. 2006. Análise de variância (ANOVA). São Paulo, Editora Atlas.

Volpedo, A.V. \& Echeverría, D.D. 2001. Morfología y morfometria de las sagittae de sciaenidos marinos del Norte de Peru. Boletín de la Sociedad de Biología de Concepción, 72: 147-154.

Wilson, J.A.; Vigliola, L. \& Meekan, M.G. 2009. The backcalculation of size and growth from otoliths: Validation and comparison of models at an individual level. Journal of Experimental Marine Biology and Ecology, 368(1): 9-21.

Wootton, R.J. 1998. Ecology of teleost fishes. 2.ed. London, Ed. Kluwer Academic Publishers.

YAmaguti, N. 1979. Diferenciação geográfica de Macrodon ancylodon (Bloch \& Schneider, 1801) na costa brasileira, entre as latitudes $18^{\circ} 36^{\prime} \mathrm{S}$ (Conceição da Barra, ES e $32^{\circ} 10^{\prime} \mathrm{S}$ (Barra do Rio Grande, RS). Etapa I. Boletim do Instituto Oceanográfico, 28(1): 53-118.

Zar, J.H. 2010. Biostatiscal analysis. New Jersey, Pearson Prentice Hall.

Aceito em: 14/11/2013

Publicado em: 30/09/2014

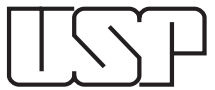

Publicado com o apoio financeiro do Programa de Apoio às Publicações Científicas Periódicas da USP 